Dinamika Kesehatan Jurnal Kebidanan dan Keperawatan Vol 11 No. 1 Juli 2020 ( ISSN: 2086-3454 EISSN: 2549-4058)

url: http://ojs.dinamikakesehatan.unism.ac.id DOI : https://doi.org/10.33859/dksm.v11i1

Durasi Hubungan Seksual Pra Konsepsi Dengan Kejadian Preeklamsi Di Rumah Sakit Dr. H. Moch. Ansari Saleh Banjarmasin

\title{
Durasi Hubungan Seksual Pra Konsepsi Dengan Kejadian Preeklamsi Di Rumah Sakit Dr. H.
}

\section{Moch. Ansari Saleh Banjarmasin}

\author{
Lisda Handayani, Susanti Suhartati \\ Program Studi Pendidikan Profesi Bidan Universitas Sari Mulia \\ *correspondence author: *Telepon: 05 I 1-32681 05, Fax:0511-3270134, \\ E-mail : lisdada.sm@gmail.com
}

\section{DOI: $\underline{10.33859 / \mathrm{dksm} . \mathrm{v} 11 \mathrm{i1} .561}$}

\begin{abstract}
Abstrak
Latar Belakang: Penyakit hipertensi dalam kehamilan (Preeklamsia dan Eklamsia) adalah salah satu dari tiga penyebab utama kematian ibu disamping perdarahan dan infeksi. Ada sekitar $85 \%$ preeklamsia terjadi pada kehamilan pertama. Durasi hubungan seksual yang pendek lebih sering terjadi pada wanita dengan preeklamsi dibanding dengan kehamilan tanpa komplikasi

Tujuan: Mengetahui apakah ada hubungan antara durasi hubungan seksual pra konsepsi dengan kejadian preeklamsi pada ibu primipara di RSUD dr. H. Moch Ansari Saleh Banjarmasin.

Metode: Penelitian ini menggunakan survey analitik dengan pendekatan cross sectional. populasi dalam penelitian ini adalah semua ibu bersalin primipara yang melahirkan di RSUD H. Moch Ansari Saleh Banjarmasin dengan Teknik accidental sampling sebanyak 30 orang ibu. analisis data menggunakan chi square.

Hasil: Hasil penelitian menunjukkan angka kejadian preeklamsi pada ibu primipara adalah 23,3\%, durasi hubungan seksual pra konsepsi paling banyak lebih dari 1 tahun yaitu 56,7\%. berdasarkan hasil analisis chi square didapatkan tidak ada hubungan antara durasi hubungan seksual pra konsepsi dengan kejadian preeklamsi pada ibu primipara. hal ini terjadi karena dari 7 orang ibu preeklamsi, 6 diantaranya $(85,7 \%)$ jarak menikah 2-17 tahun, artinya umur dan penggunaan kontrasepsi mungkin memiliki peran terhadap kejadian tersebut.
\end{abstract}

Kata Kunci: Preeklamsi, durasi hubungan seksual, primipara, 


\section{Abstract}

Background: Hypertension in pregnancy (Preeclampsia and Eclampsia) is one of the three main causes of maternal death besides bleeding and infection. About $85 \%$ of preeclampsia occurs in the first pregnancy. Short duration of sexual intercourse is more common in women with preeclampsia compared to uncomplicated pregnancies

Objective: To know relation between duration of sexual intercourse with the incidence of preeclampsia in primiparous mothers in dr. H. Moch Ansari Saleh Banjarmasin hospital.

Method: This study used analytic survey with cross sectional approach. the population is all of primiparous mothers who giving birth at H. Moch Ansari Saleh Hospital Banjarmasin with an accidental sampling technique of 30 mothers. analysis using chi square.

Results: The results showed the incidence of preeclampsia in primiparous mothers was $23.3 \%$, the duration of pre-conception of sexual intercourse was at most more than 1 year at $56.7 \%$. based on the results of chi square analysis found no relationship between the duration of sexual intercourse with the incidence of preeclampsia in primiparous mothers. this happened because of 7 preeclampsia mothers, 6 of them (85.7\%) were married 2-17 years apart, meaning that age and contraceptive may had a role in the incident.

Keywords: Preeclampsia, duration of sexual intercourse, primiparous

\section{PENDAHULUAN}

Penyakit hipertensi dalam kehamilan (Preeklamsia dan Eklamsia) adalah salah satu dari tiga penyebab utama kematian ibu disamping perdarahan dan infeksi. Ada sekitar $85 \%$ preeklamsia terjadi pada kehamilan pertama. Menurut WHO terdapat sekitar $585.000 \mathrm{ibu}$ meninggal per tahun saat hamil atau bersalin dan 58,1\% diantaranya dikarenakan oleh preeklamsia dan eklamsia. Di Indonesia, preeklamsi dan eklamsi merupakan penyebab kematian ibu yang berkisar 15\% - 25\% (Bobak dkk, 2005). Sistem penilaian risiko tidak dapat memprediksi apakah ibu hamil akan bermasalah selama kehamilannya. Oleh karena itu bidan sebagai pemberi asuhan harus mampu mengenali faktor risiko yang mugkin terjadi dan mendeteksi secara dini adanya komplikasi selama kehamilan, karena kehamilan dapat berkembang menjadi masalah atau komplikasi setiap saat (Maternity dkk, 2014). Banyak faktor yang diidentifikasi menjadi faktor risiko preeklamsi antara lain paritas, kehamilan ganda, usia kurang dari 20 tahun atau lebih dari 35 tahun, memiliki riwayat keluarga, obesitas serta riwayat penyakit sistemik yang pernah diderita. Akan tetapi di anatara faktorfaktor tersebut masih sulit menentukan mana yang menjadi faktor dominan. Peningkatan risiko hipertensi terjadi pada wanita mengalami preeklampsia berat/ eklampsia pada kehamilan pertama. Preeklamsi sering mengenai perempuan muda dan nulipara, sedangkan perempuan lebih tua lebih berisiko mengalami hipertensi kronis yang bertumpang 
Dinamika Kesehatan Jurnal Kebidanan dan Keperawatan Vol 11 No. 1 Juli 2020 ( ISSN: 2086-3454 EISSN: 2549-4058)

url: http://ojs.dinamikakesehatan.unism.ac.id DOI : https://doi.org/10.33859/dksm.v11i1

Durasi Hubungan Seksual Pra Konsepsi Dengan Kejadian Preeklamsi Di Rumah Sakit Dr. H. Moch. Ansari Saleh Banjarmasin

tindih dengan preeklamsi-eklamsi

(Cuningham dkk, 2014). Insiden preeklampsia

berat lebih banyak terjadi pada wanita nulipara dibandingkan dengan wanita multipara.

Mekanisme genetik dan imunologi diduga berperan dan sedang banyak diteliti. Banyak gen yang diduga berperan antara lain gen activin A serta androgen receptor serta berbagai polimorfismenya. Risiko preeklampsi 2 sampai 5 kali lipat lebih tinggi pada wanita hamil dengan riwayat preeklamsi (Yusrawati dkk, 2014). Berdasarkan Dekker (2014) diketahui bahwa durasi hubungan seksual yang pendek lebih sering terjadi pada wanita dengan preeklamsi dibanding dengan kehamilan tanpa komplikasi. Hal yang sama telah diteliti Zhang (1997) bahwa durasi hubungan seksual prakonsepsi dan jumlah anprotcted intercourse berbanding terbalik dengan kejadian preeklamsi bila anprotcted intercourse jarang dan tidak lama durasinya, maka akan meningkatkan risiko terjadinya preeklamsi. Melihat semakin banyaknya faktor risiko preeklamsia yang telah diidentifikasi dan belum terdapat data tentang durasi hubungan seksual prakonsepsi terhadap kejadian preeklamsi.

\section{METODE}

Penelitian ini menggunakan metode survey analitik dengan pendekatan cross sectional. Jenis data dalam penelitian ini adalah kuantif dengan sumber data menggunakan data primer. Populasi dalam penelitian ini adalah semua ibu primipara diruang nifas RSUD Dr.

H. Moch Ansari Saleh Banjarmasin, dengan Teknik sampel menggunakan accidental sampling sebanyak $30 \mathrm{ibu}$. Pengambilan data primer menggunakan checklist dan dilakukan Analisis bivariate menggunakan chi square.

\section{HASIL PENELITIAN}

\section{ANALISIS UNIVARIAT}

\section{a. Preeklamsi}

Tabel 1. distribusi frekuensi kejadian preeklampsi pada ibu primipara di RSUD Dr. H. Moch Ansari Saleh Banjarmasin

\begin{tabular}{lcc}
\hline Preeklampsi & $\mathrm{n}$ & $\%$ \\
\hline Tidak & 23 & 77,7 \\
Ya & 7 & 23,3 \\
\hline Total & 30 & 100 \\
\hline
\end{tabular}

berdasarkan tabel 1, diketahui dari 30 orang ibu primipara yang melahirkan di RSUD dr. H. Moch Ansari Saleh Banjarmasin paling banyak adalah ibu yang tidak mengalami preeklampsi (77,7\%) sedangkan ibu yang mengalami preeklampsi sebanyak 7 orang $(23,3 \%)$.

\section{b. Durasi Hubungan Seksual}

Tabel 2. distribusi frekuensi durasi hubungan seksual pada ibu primipara di RSUD Dr. H. Moch Ansari Saleh Banjarmasin

\begin{tabular}{lcc}
\hline $\begin{array}{l}\text { Durasi } \\
\text { hubungan }\end{array}$ & $\mathrm{N}$ & $\%$ \\
\hline$<1$ tahun & 13 & 43,3 \\
$>1$ tahun & 17 & 56,7 \\
\hline Total & 30 & 100 \\
\hline
\end{tabular}


berdasarkan tabel 2, diketahui bahwa dari 30 ibu bersalin primipara di RSUD dr. H. Moch Ansari Saleh paling banyak melakukan durasi hubungan seksualnya adalah lebih dari 1 tahun $(56,7 \%)$ sedangkan yang kurang dari 1 tahun ada $13 \mathrm{ibu}(43,3 \%)$.

\section{ANALISIS BIVARIAT}

Tabel 3. hubungan durasi hubungan seksual dengan kejadian preeklampsi pada ibu primipara di RSUD dr. H. Moch Ansari Saleh Banjarmasin

\begin{tabular}{|c|c|c|c|c|c|c|}
\hline \multirow{3}{*}{$\begin{array}{l}\text { Preekla } \\
\text { msi }\end{array}$} & \multicolumn{5}{|c|}{$\begin{array}{c}\text { Durasi hubungan } \\
\text { seksual }\end{array}$} & \multirow{3}{*}{$\begin{array}{c}\text { Jumlah } \\
\%\end{array}$} \\
\hline & \multicolumn{3}{|c|}{$<1$ tahun } & \multicolumn{2}{|c|}{$\begin{array}{c}>1 \\
\text { tahun }\end{array}$} & \\
\hline & $\mathrm{n}$ & $\%$ & $\mathrm{n}$ & $\%$ & $\mathrm{n}$ & \\
\hline Tidak & 12 & 40 & $\begin{array}{l}1 \\
1 \\
\end{array}$ & 36,7 & 23 & 76,7 \\
\hline $\mathrm{Ya}$ & 1 & 3,3 & 6 & 20 & 7 & 23,3 \\
\hline Total & 13 & $\begin{array}{c}43 \\
3\end{array}$ & $\begin{array}{l}1 \\
7\end{array}$ & 56,7 & 30 & $100 \%$ \\
\hline
\end{tabular}

Berdasarkan hasil uji statistic menggunakan komputer diketahui bahwa tidak ada hubungan yang signifikan antara durasi hubungan seksual dengan kejadian preeklamsi pada ibu primipara di RSUD dr. H. Moch Ansari Saleh Banjarmasin, dengan p value $0,077(\mathrm{p}>\alpha)$.

\section{PEMBAHASAN}

Preeklamsi dalam kehamilan adalah apabila dijumpai tekanan darah 140/90 mmHg setelah kehamilan 20 minggu (akhir triwulan kedua sampai triwulan ketiga) atau bisa lebih awal terjadi. Preeklamsi adalah salah satu kasus gangguan kehamilan yang bisa menjadi penyebab kematian ibu. (Maternity dkk, 2014).

Pada primipara sering mengalami stress dalam menghadapi persalinan. Stress emosi yang terjadi pada primipara menyebabkan peningkatan pelepasan corticotropicreleasing hormone $(\mathrm{CRH})$ oleh hipothalamus, yang kemudian menyebabkan peningkatan kortisol. Efek kortisol adalah mempersiapkan tubuh untuk berespons terhadap semua stresor dengan meningkatkan respons simpatis, termasuk respons yang ditujukan untuk meningkatkan curah jantung dan mempertahankan tekanan darah. Pada wanita dengan preeklamsi / eklamsi, tidak terjadi penurunan sensitivitas terhadap vasopeptida-vasopeptida tersebut, sehingga peningkatan besar volume darah langsung meningkatkan curah jantung dan tekanan darah. Berdasarkan hasil penelitian ini diketahui bahwa dari 30 orang ibu primipara yang melahirkan di RSUD dr. H. Moch Ansari Saleh 7 orang (23,3\%) diantaranya mengalami Preeklmasi dimana preeklampsi yag dialami ibu adalah preeklmsi berat. preeklampsi berat ditandai dari Tekanan darah 160/110 $\mathrm{mmHg}$ atau lebih, protein urin +2 atau lebih, oligouria (jumlah urin kurang dari $500 \mathrm{cc} / 24$ jam serta adanya gangguan serebral, visus dan adanya rasa nyeri pada epigastrium dan disertai adanya edema paru dan sianosis.

Pada umumnya preeklampsi diperkirakan sebagai penyakit pada 
kehamilan pertama. bila kehamilan sebelumnya normal, maka insiden preeklampsi akan menurun, bahkan abortus pada kehamilan sebelumnya merupakan faktor protektif terhadap kejadian preeklampsi. hal ini terjadi karena pada ibu primi pembentukan antibody penghambat belum sempurna sehingga meningkatkan risiko terjadinya preeklampsi (Indriani, 2012).

Preeklampsi merupakan salah satu penyulit kehamilan yang belum diketahui pasti penyebabnya, salah satu teori yang dikemukakan adalah faktor imunologis. berdasarkan beberapa penelitian menemukan bahwa durasi hubungan seksual prakonsepsi dan jumlah unprotected intercourse berbanding terbalik dengan kejadian preeklampsi/eklampsi. Bila unprotected intercourse jarang dan tidak lama durasinya maka akan meningkatkan risiko terjadinya preeklampsi/eklampsi. jani mengandung antigen dari ayahnya yang asing bagi ibu yang sedang hamil tersebut (Zhaang, 1997).

Berdasarkan hasil penelitian diketahui bahwa pada ibu bersalin primipara di RSUD dr. H. Moch Ansari Saleh Banjarmasin lebih banyak ibu dengan durasi hubungan seksual prakonsepsi lebih dari 1 tahun (56,7\%) dengan rentang waktu 2-17 tahun. ibu yang hamil dengan durasi hubungan seksual prakonsepsi kurang dari 1 tahun hanya 43,3\%. sedangkan berdsarkan analisis bivariate diketahui bahwa tidak ada hubungan yang bermakna antara durasi hubungan seksual dengan kejadian preeklampsi pada ibu primipara di RSUD dr. H. Moch Ansari Saleh Banjarmasin dengan p I 0,077 ( $p>\alpha)$. Hal ini bertolak belakang dengan hasil penelitian yang mengatakan bahwa Gangguan hipertensi yang diinduksi kehamilan, dan terutama preeklampsia, didokumentasikan terjadi terutama pada kehamilan pertama dan jarang pada kehamilan berikutnya. Oleh karena itu, konsep primigraviditas adalah landasan epidemiologis penyakit ini. Para penulis mengusulkan konsep di mana preeklampsia adalah penyakit pasangan baru (Robillard et al, 1999). artinya dari penelitian ini disebutkan bahwa preeklampsi lebih berisiko pada pasangan yang baru menikah yang durasi hubungan seksual prakonsepsi lebih pendek lebih berisiko mengalami preeklampsi. Penelitian lain mengatakan wanita dengan masa hidup bersama yang pendek (kurang dari 4 bulan) yang menggunakan metode kontraspsi penghalang risiko terjadinya preeklampsi meningkat dibandingkan dengan pada wanita yang jarak hubungan seksualnya lebih dari 12 bulan sebelum kehamilan (Einarsson, 2003). artinya, preeklampsi lebih berisiko terjadi pada durasi hubungan seksual prakonsepsi yang kurang dari 1 tahun. Hasil penelitian ini menunjukkan bahwa dari 7 orang ibu preeklampsi, 6 diantaranya $(85,7 \%)$ terjadi pada ibu yang menikah sudah lebih dari 1 tahun dengan jarak pernikahan dan kehamilan antara 2-17 tahun. Penelitian lain yang mendukung hasil penelitian ini 
menyebutkan bahwa jarak hubungan seksual yang lebih panjang memberikan perlindungan parsial terhadap kehamilan yang berkaitan dengan aliran darah ke uterus (Kho et al, 2009). Perbedaan hasil penelitian ini dapat dilihat berdasarkan jarak antara menikah dengan kehamilan yang cukup jauh, yang dapat dikaitkan dengan umur ibu dimana semakin besar jarak menikah dengan kehamilan maka semakin tinggi usia ibu yang menyebabkan semakin berisiko ibu dalam kehamilan sehingga menyebabkan terjadinya komplikasi dalam kehamilan. selain faktor umur adalah faktor penggunaan kontrasepsi. Perkembangan fisik manusia sejalan dengan pertambahan umur dalam hal ini berhubungan dengan proses degeneratif yang menyebabkan terjadinya pengerasan pada dinding pembuluh darah yang selanjutnya terjadi penyempitan. Pembuluh darah memerlukan tekanan lebih banyak disesuaikan dengan banyak hambatan, untuk memompa aliran darah. Semakin bertambah umur seseorang, hambatan semakin banyak maka risiko terjadinya hipertensi juga semakin banyak. Risiko terjadinya hipertensi bertambah banyak apabila wanita tersebut juga menggunakan kontrasepsi terutama kontrasepsi hormonal. Kontrasepsi hormonal berupa pil KB sebagian besar mengandung hormon estrogen dan pregesteron. Hormon dalam kontrsepsi ini telah diatur sedemikian rupa sehingga mendekati kadar hormone dalam tubuh akseptor namun bila digunakan dalam jangka waktu yang lama akan timbul efek samping lain. Kedua hormon tersebut memiliki kemampuan untuk mempermudah retensi ion natrium dan sekresi air disertai kenaikan aktivitas rennin plasma dan pembentukan angiontensin sehingga dapat memicu terjadinya peningkatan tekanan darah (Setiawan, 2016)

\section{UCAPAN TERIMAKASIH}

Peneliti mengucapkan terimakasih kepada Direktur RSUD Dr.H.Moch Ansari Saleh karena telah memberikan ijin dalam melakukan penelitian di RSUD Dr.H.Moch Ansari Saleh dan juga mengucapkan terimakasih kepada Universitas Sari Mulia yang telah memberikan dukungan terhadap pelaksanaan penelitian ini. Semoga hasil penelitian dapat berguna dalam peningkatkatan pelayanan dan pendidikan kesehatan khususnya bidan di indonesia.

\section{DAFTAR PUSTAKA}

Bobak; Lowdermilk \& Jensen. 2005. Buku Ajar Keperawatan Maternitas. Jakarta. EGC

Cuningham; Leveno; Bloom dkk. 2012. Obstetri Williams. Jakarta. EGC

Dekker, Gus; Robilliard, Pierre Yves \& Roberts, Claire. 2011. The etiology of Preeclampsia:

the Role of the Father. Journal of Reproductive Immunology Volume 89 Halaman 126132 
Einarsson, Jon I; Haghpaykar, Haleh Sungi; Gardener, Michael O. 2003. Am.J.Obstetr Gynecol Vol. 188, Nomor 5

Indriani, Nanien. 2012.Analisis Faktor-faktor yang Berhubungan dengan Preeklampsia/eklampsia pada Ibu Bersalin di Rumah Sakit Umum Daerah Kardinah Kota Tegal. Skripsi; Universitas Indonesia Jakarta

Kho, E.M., McCowan, L.M., North, R.A., Roberts, C.T., Chan, E., Black, M.A., Taylor, R.S., Dekker, G.A., SCOPE Consortium, 2009. Duration of sexual relationship and its effect on preeclampsia and small for gestational age perinatal outcome. J. Reprod. Immunol. 82, 66-73.

Maternity, Dainty; Yantina, Yuli \& Putri, Ratna Dewi. 2014. Asuhan Kebidanan Patologis.

Tangerang. Binarupa Aksara Publisher

Radjamuda, Nelawati \& Montolalu, Agnes. 2014. Faktor-Faktor yang Berhubungan dengan Kejadian Hipertensi pada Ibu Hamil di Poli Klinik Obs-Gin Rumah Sakit Jiwa Prof. Dr. V.L. Ratumbuysang Kota Manado. Jurnal Ilmiah Bidan. Volume 2 Nomor 1

Robillard, P.Y., Dekker, G., Chaouat, G., Hulsey, T.C., 2007. Etiology of preeclampsia: maternal vascular predisposition and couple disease mutual exclusion or complementarity? J. Reprod. Immunol. 76, 1-7.

Setiawan, Rizky Perdana. 2016. Hubungan Paritas dan Kontrasepsi dengan Preekmlampsia di Puskesmas Jagir. Jurnal Berkala Epidemiologi Vol.4, Nomor 1
Yusrawati; Saputra, Nicko Pisceki Kusika \& Machmud, Rizaldi. 2014. Faktor Resiko Individual pada Preeklampsia pada RSUP dr. M. Djamil Padang. OBGIN EMAS. Tahun V, Volume 1, Nomor 15

Zhang, J et al. 1997. Epidemiology Of Pregnancy-Induced Hypertantion, Epidemiology.

National Library of Medicine National Institute of Health. Volume 19 (2) Hal 18-32 